\title{
Clinical, radiological, and histological features and treatment outcomes of supratentorial extraventricular ependymoma: 14 cases from a single center
}

\author{
Shoujia Sun, MD, ${ }^{1}$ Junwen Wang, MD, PhD, ${ }^{1}$ Mingxin Zhu, MD, PhD, ${ }^{1}$ \\ Rajluxmee Beejadhursing, MD, ${ }^{1}$ Pan Gao, MD, ${ }^{1}$ Xiaojing Zhang, MD, ${ }^{1}$ Liwu Jiao, MD, ${ }^{1}$ \\ Wei Jiang, MD, PhD, ${ }^{1}$ Changshu Ke, MD, PhD, ${ }^{2}$ and Kai Shu, MD, PhD'

\begin{abstract}
Departments of ${ }^{1}$ Neurosurgery and ${ }^{2}$ Pathology, Tongji Hospital, Tongji Medical College of Huazhong University of Science and Technology, Wuhan, Hubei, People's Republic of China
\end{abstract}

\begin{abstract}
OBJECTIVE Reports on supratentorial extraventricular ependymoma (STE) are relatively rare. The object of this study was to analyze the clinical, radiological, and histological features and treatment outcomes of 14 patients with STE.

METHODS Overall, 227 patients with ependymoma underwent surgical treatment in the authors' department between January 2010 and June 2015; 14 of these patients had STE. Data on clinical presentation, radiological studies, histopathological findings, surgical strategies, and treatment outcomes in these 14 cases were retrospectively analyzed.

RESULTS The patients consisted of 6 women and 8 men (sex ratio 0.75 ). Mean age at diagnosis was $24.5 \pm 13.5$ years (range 3-48 years). Tumors were predominantly located in the frontal and temporal lobes (5 and 4 cases, respectively). Typical radiological features were mild to moderate heterogeneous tumor enhancements on contrast-enhanced MRI. Other radiological features included well-circumscribed, "popcorn" enhancement and no distinct adjoining brain edema. Gross-total resection was achieved in 12 patients, while subtotal removal was performed in 2. Radiotherapy was administered in 7 patients after surgery. Seven tumors were classified as WHO Grade II and the other 7 were verified as WHO Grade III. The mean follow-up period was 22.6 months (range 8-39 months). There were 3 patients with recurrence, and 2 of these patients died.
\end{abstract}

CONCLUSIONS Supratentorial extraventricular ependymoma has atypical clinical presentations, various radiological features, and heterogeneous histological forms; therefore, definitive diagnosis can be difficult. Anaplastic STE shows malignant biological behavior, a higher recurrence rate, and a relatively poor prognosis. Gross-total resection with or without postoperative radiotherapy is currently the optimal treatment for STE.

https://thejns.org/doi/abs/10.3171/2017.1.JNS161422

KEY WORDS ependymoma; supratentorial; extraventricular; treatment strategy; oncology

$\mathrm{E}$ PENDYMOMAS are relatively rare neuroepithelial neoplasms that account for $1.2 \%-7.8 \%$ of all intracranial tumors and $2 \%-9 \%$ of all neuroepithelial tumors. ${ }^{4,11,28}$ These neoplasms afflict both children and adults. According to the 2007 and the 2016 WHO classifications of CNS tumors, ependymomas are classified as Grade I (subependymoma and myxopapillary ependymoma), Grade II (ependymoma), and Grade III (anaplastic ependymoma). ${ }^{12,13}$ Approximately one-third of ependymomas are located supratentorially, ${ }^{21}$ whereas supratentorial extraventricular ependymomas (STEs) and cortical ependymomas (CEs) are relatively infrequent. About 45 cases of STE have been reported, the majority as case reports. ${ }^{11}$ Resection is the first-choice treatment for STE; however, there has been open controversy within the neuro-oncology community regarding the optimal postoperative treatment for adults with STE. 19,28

In this report, we retrospectively analyzed the clinical characteristics, neuroimaging findings, pathological features, and treatment outcomes of 14 patients with STE who

ABBREVIATIONS CE = cortical ependymoma; EMA = epithelial membrane antigen; GFAP = glial fibrillary acidic protein; GTR = gross-total resection; STE = supratentorial extraventricular ependymoma; STR = subtotal resection.

SUBMITTED June 5, 2016. ACCEPTED January 19, 2017.

INCLUDE WHEN CITING Published online July 7, 2017; DOI: 10.3171/2017.1.JNS161422. 
had been surgically treated in our department between January 2010 and June 2015. To the best of our knowledge, this is one of the largest case series to be conducted and may contribute to the clinical understanding of STE.

\section{Methods}

Between January 2010 and June 2015, 227 cases of ependymoma underwent surgical treatment at Wuhan Tongji Hospital. Sixty-two cases $(27.3 \%)$ presented with supratentorial locations, 14 cases $(6.2 \%)$ were identified as STE, and 13 cases $(5.7 \%)$ were identified as CE. The 14 cases of STE occurred in 6 women and 8 men. Clinical data regarding patient age, sex, clinical presentation, neurological examinations, neuroimaging findings, histopathological features, and treatment outcomes were evaluated in this study. Ethics approval was obtained from the local authorities in accordance with the Helsinki criteria, and written informed consent was obtained from each patient.

In all cases, tumor tissues were formalin-fixed, paraffin-embedded, and cut in 4- $\mu \mathrm{m}$-thick sections that were prepared for $\mathrm{H} \& \mathrm{E}$ and immunohistochemical staining, using the following antibodies in the differential diagnosis: glial fibrillary acidic protein (GFAP), S100 protein, epithelial membrane antigen (EMA), CD99, and MIB1 (Ki-67), among others. All cases were analyzed by an experienced independent neuropathologist and were diagnosed according to the WHO classification of central nervous system tumors. ${ }^{12,13}$

All patients were followed up in the outpatient department. The radiological evidence was used as the monitoring indicator of recurrence. The independent-samples t-test was used to compare Ki-67 in the different grades, and $p<0.05$ was considered statistically significant.

\section{Results}

Mean age at diagnosis in the 14 patients (sex ratio 0.75) with STE was $24.5 \pm 13.5$ years (range $3-48$ years). Seven tumors $(50 \%)$ were located in the left hemisphere, 6 $(42.8 \%)$ in the right hemisphere, and $1(7.1 \%)$ in the saddle area. The most frequent locations for tumor were the frontal and temporal lobes (5 and 4 cases, respectively; Fig. $1 \mathrm{~A}$ and $\mathrm{B})$. In addition, there were 2 cases with tumor located in the parietal lobe, 1 case in the occipital lobe, 1 case in the parietooccipital lobe, and 1 case in the saddle area (Fig. 1C-F). Common symptoms included headache ( 7 cases [50\%]), seizures (4 cases [28.6\%]), weakness, and limb numbness. Clinical presentations, neuroimaging findings, and treatment outcomes for the 14 patients are summarized in Table 1. All patients underwent CT and MRI before surgery. Calcification was observed in 3 cases on preoperative CT scans. All tumors showed mild to moderate heterogeneous enhancement on MRI. Eight cases demonstrated a solid appearance and 6 cases showed a concomitant solid and cystic appearance. Other radiological features included well-circumscribed, "popcorn" appearance after enhancement and no distinct surrounding brain edema (Figs. 1-3).

All resected tumors were subjected to immunohistochemistry examinations, whose results are summarized in
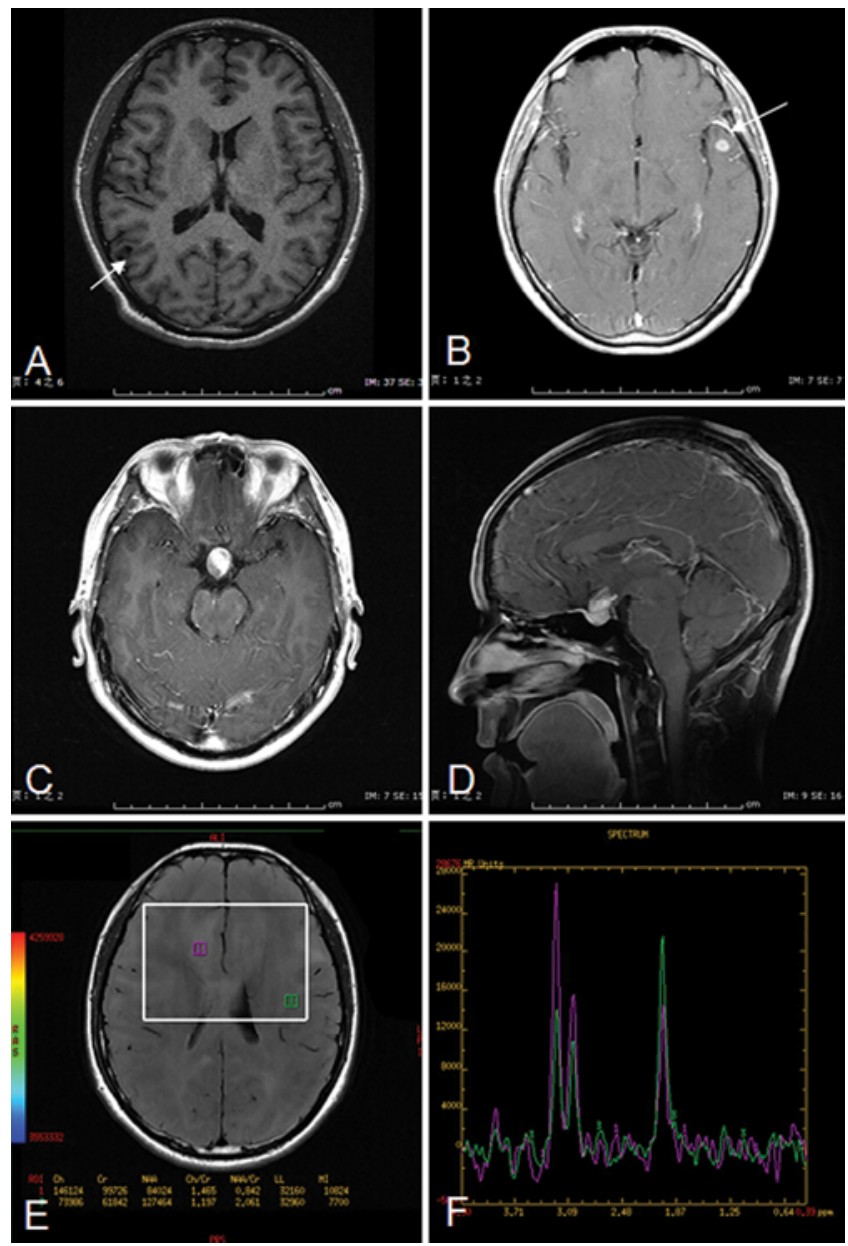

FIG. 1. Case 11. A solid, cystic lesion (arrow) located in the posterior temporal lobe (A). Case 4. A solid lesion (arrow) located in the anterior temporal lobe (B). Case 3. Axial (C) and sagittal (D) enhanced MR images showed a solid, heterogeneously enhancing lesion in the saddle and suprasellar area. Magnetic resonance spectra on adjacent parenchyma showed prominent resonance from choline, small lactate doublet, small $\mathrm{N}$-acetylaspartate resonance, and high myoinositol signals ( $\mathrm{E}$ and F). Figure is available in color online only.

Table 2. According to the WHO classification, 7 tumors were diagnosed Grade II (ependymoma) and the other 7 were diagnosed as WHO Grade III (anaplastic ependymoma). Immunohistochemical studies revealed that the tumor cells were strongly positive for GFAP (13 of 14 cases), vimentin (11 of 14), S100 protein (10 of 14), and EMA (8 of 14) and partially positive for Nestin (5 of 14), MGMT (3 of 14), and Olig-2 (3 of 14). The Ki-67 proliferation index ranged from $<1 \%$ to $60 \%$, and the value of Grade III cases apparently exceeded that of the Grade II cases $(\mathrm{p}<0.05)$. Classic ependymal features and focal perivascular pseudorosette formation were observed in all cases (Fig. 2).

Gross-total resection (GTR) was achieved in 12 cases and subtotal resection (STR) was performed in 2 cases. Seven patients with STE accepted radiotherapy treatment after surgery. These 7 patients were diagnosed with WHO Grade III tumors and 2 of them had undergone STR. The radiation dose ranged from 5040 cGy over 28 fractions to 
TABLE 1. Summary of 14 cases of STE

\begin{tabular}{|c|c|c|c|c|c|c|c|c|c|c|c|c|}
\hline $\begin{array}{l}\text { Case } \\
\text { No. }\end{array}$ & Sex & $\begin{array}{c}\text { Age at } \\
\text { Resection } \\
\text { (yrs) }\end{array}$ & Presentation & Location & $\begin{array}{l}\text { WHO } \\
\text { Grade }\end{array}$ & $\begin{array}{c}\text { Type of } \\
\text { Resection }\end{array}$ & $\begin{array}{l}\text { Radiation } \\
\text { Therapy }\end{array}$ & Recurrence & $\begin{array}{c}\text { FU } \\
\text { (mos) }\end{array}$ & Status & $\begin{array}{c}\text { Preop CT } \\
\text { Calcification }\end{array}$ & $\begin{array}{c}\text { MRI } \\
\text { Features }\end{array}$ \\
\hline 1 & $M$ & 19 & Numbness & Lt parietal & II & GTR & NR & No & 8 & Alive & No & Solid \\
\hline 2 & $\mathrm{~F}$ & 26 & $\begin{array}{l}\text { Headache, } \\
\text { weakness }\end{array}$ & $\begin{array}{l}\text { Rt fronto- } \\
\text { parietal }\end{array}$ & III & GTR & $\begin{array}{l}5940 \\
\text { cGy/33 F }\end{array}$ & No & 15 & Alive & No & $\begin{array}{l}\text { Solid \& } \\
\text { cystic }\end{array}$ \\
\hline 3 & $\mathrm{M}$ & 48 & Headache & $\begin{array}{l}\text { Saddle } \\
\text { area }\end{array}$ & III & GTR & $\begin{array}{l}5400 \\
\quad \text { CGy/30 F }\end{array}$ & No & 34 & Alive & No & Solid \\
\hline 4 & $M$ & 24 & Seizures & Lt temporal & II & GTR & NR & No & 30 & Alive & Yes & Solid \\
\hline 5 & $\mathrm{M}$ & 6 & $\begin{array}{r}\text { Headache, } \\
\text { vomiting }\end{array}$ & Lt frontal & III & STR & $\begin{array}{l}5040 \\
\quad \text { CGy/28 F }\end{array}$ & Yes & 25 & $\begin{array}{c}\text { Died at } 25 \\
\text { mos }\end{array}$ & No & Solid \\
\hline 6 & $\mathrm{~F}$ & 30 & $\begin{array}{l}\text { Headache, } \\
\text { vomiting }\end{array}$ & Lt occipital & II & GTR & NR & No & 25 & Alive & No & Solid \\
\hline 7 & $M$ & 22 & $\begin{array}{l}\text { Headache } \\
\text { (hemorrhage) }\end{array}$ & $\begin{array}{l}\text { Rt tempo- } \\
\text { ral }\end{array}$ & III & GTR & $\begin{array}{l}5520 \\
\text { cGy/29 F }\end{array}$ & Yes & 22 & $\begin{array}{c}\text { Died at } 22 \\
\text { mos }\end{array}$ & No & Solid \\
\hline 8 & $\mathrm{M}$ & 31 & Headache & Rt frontal & III & STR & $\begin{array}{l}5880 \\
\quad \text { cGy/28 F }\end{array}$ & No & 28 & Alive & Yes & $\begin{array}{l}\text { Solid \& } \\
\text { cystic }\end{array}$ \\
\hline 9 & $\mathrm{~F}$ & 18 & Dizziness & Lt temporal & II & GTR & NR & No & 32 & Alive & No & Mostly solid \\
\hline 10 & $\mathrm{~F}$ & 3 & Seizures & Rt frontal & III & GTR & $\begin{array}{l}5040 \\
\quad \text { cGy/28 F }\end{array}$ & No & 15 & Alive & No & $\begin{array}{l}\text { Solid \& } \\
\quad \text { cystic }\end{array}$ \\
\hline 11 & M & 22 & Seizures & $\begin{array}{l}\text { Rt tempo- } \\
\quad \text { ral }\end{array}$ & $\|$ & GTR & NR & No & 14 & Alive & No & $\begin{array}{l}\text { Solid \& } \\
\text { cystic }\end{array}$ \\
\hline 12 & $F$ & 11 & Vomiting & $\begin{array}{l}\text { Lt parieto- } \\
\text { occipital }\end{array}$ & $\|$ & GTR & NR & No & 8 & Alive & No & $\begin{array}{l}\text { Solid \& } \\
\text { cystic }\end{array}$ \\
\hline 13 & $M$ & 48 & Headache & Lt frontal & II & GTR & NR & No & 39 & Alive & Yes & Solid \\
\hline 14 & $F$ & 35 & Seizures & Rt parietal & III & GTR & $\begin{array}{l}5040 \\
\quad \text { cGy/28 F }\end{array}$ & Yes & 21 & Alive & No & $\begin{array}{l}\text { Solid \& } \\
\text { cystic }\end{array}$ \\
\hline
\end{tabular}

$F=$ fractions; $F U=$ follow-up; $N R=$ not received.

5940 cGy over 33 fractions, with a mean of 5408 cGy. The follow-up period ranged from 8 to 39 months, with a mean duration of 22.6 months. In the follow-up period, tumors recurred in 3 cases, resulting in progression-free survival times of 18,15 , and 18 months; 2 of the patients died of tumor recurrence. One case of relapse is under close observation with 6-month interval follow-up.

\section{Discussion}

Both STEs and CEs are very uncommon tumors. The majority of publications on STE are case reports, indicating an urgent need for reports with large series of STEs from a single center. ${ }^{11}$ To fill this gap, we here describe 14 cases $(6.2 \%)$ of STE (13 cases of CE) to provide more insight into these tumors. The lesions often occurred in young patients (mean age 24.5 years), which is consistent with previous observations documented in the literature. ${ }^{11,27}$ The tumors were commonly located in the frontal and temporal lobes (5/14 and 4/14, respectively), which relates to the entity's common presenting symptom, epilepsy. This finding is different from data in previous reports that have found a low frequency of CEs in the temporal lobe $(1 / 16) .{ }^{11,29}$ To the best of our knowledge, no report has described the growth of STE. In our study, the postcontrast T1-weighted images in Case 2, which were obtained at different times, revealed the rapid growth of an anaplastic ependymoma (Fig. 2). A solid, heterogeneously enhancing lesion in the saddle and suprasellar area was found in the patient in Case 3, and the patient underwent GTR via a transsphenoidal approach. Intrasellar ependymoma has rarely been reported, and transsphenoidal resection is an effective approach for resection of this tumor. Ependymomas should be considered in the differential diagnosis of intrasellar lesions. ${ }^{22}$

The pathogenesis of the STE remains elusive. Ependymal cells that extend periventricularly deep into the adjacent white matter or fetal remnants of the ependymal cells have been hypothesized to be the cellular origin of these neoplasms. ${ }^{2,7,26}$ However, the random distribution of ependymomas around the periventricular region in many previous studies makes this hypothesis controversial. The clinicopathological features of CEs are similar to those of ectopic ependymomas in many respects. The fact that ectopic ependymomas occur in sites at which a normal ependymal layer is absent suggests that these neoplasms may originate from a cell type other than terminally differentiated ependymal cells. ${ }^{23}$ An ectopic retinal ependymoma that was proposed to arise from Müller cells indicated that glial cells with progenitor cell properties are the source of these ependymomas. ${ }^{9}$ Extracerebral ependymomas that occur in ovaries are also believed to be derived from progenitor cells, and their occurrence in teratomas seems to 

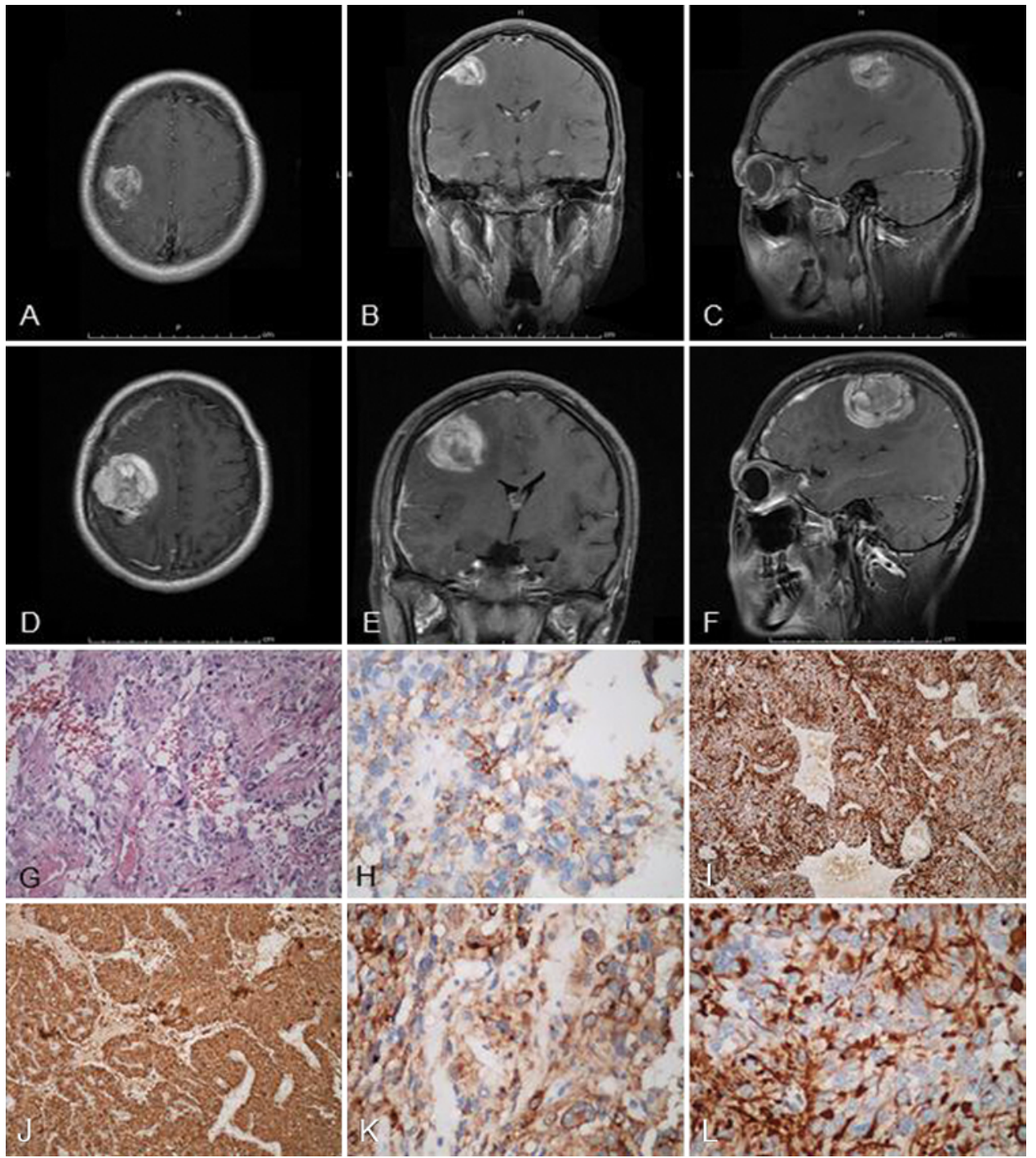

FIG. 2. Case 2. Enhanced MR images (A-C) obtained 4 months before surgery, showing a cystic and solid tumor mass located in the right frontoparietal lobe. The tumor size was about $37.92 \times 40.11 \times 33.68 \mathrm{~mm}$. Enhanced MR images (D-F) obtained just before surgery, demonstrating a tumor size of about $49.25 \times 46.26 \times 41.53 \mathrm{~mm}$, which had increased nearly 1.84 times in 4 months. H \& E staining (G) demonstrated typical histological features of perivascular pseudorosettes and nuclear atypia, mitotic activity, endothelial cell hyperplasia, and tumor necrosis, corresponding to anaplastic ependymoma. Epithelial membrane antigen staining (H) was focally positive. Staining with GFAP (I) was diffusely immunopositive. S100 staining (J) was positive and demonstrated a distinct papillary pattern. Synaptophysin $(\mathbf{K})$ and vimentin $(\mathbf{L})$ staining were positive. Original magnifications $\times 10(\mathrm{I}$ and $\mathrm{J}), \times 20(\mathrm{G})$, and $\times 40(\mathrm{H}, \mathrm{K}$, and $\mathrm{L})$. Figure is available in color online only.

support this view. ${ }^{3,8,18}$ A previously published paper explained why this tumor may originate from heterotopic ependymal cell rests via the rostral migratory stream (RMS) and found that the RMS contained progenitor cells. ${ }^{5}$ In the present report, the pathological diagnosis at the first operation in the 14th case was central neurocytoma. Histopathologically, typical neurocytomas are predominantly composed of uniform, small round cells with neuronal differentiation arranged in sheets, clusters, ribbons, or rosettes, and tumor cells embedded in neuropil are strongly immunoreactive for synaptophysin. ${ }^{1}$ However, the in situ pathological diagnosis at the reoperation was anaplastic ependymoma. Increased cellularity with perivascular pseudorosettes and uniform ependymal cells were observed in H \& E-stained sections (Figs. 3 and 4). Under a magnified view, $\mathrm{H} \& \mathrm{E}$-stained sections demonstrated nuclear atypia, mitotic activity, endothelial cell hyperplasia, and tumor necrosis that was consistent with anaplastic ependymoma. This interesting phenomenon may support the hypothesis that CEs originate from other cell types to some extent.

The main differential diagnoses of STE in imaging and histological sections include angiocentric glioma, pleomorphic xanthoastrocytoma, oligodendroglioma, glioblastoma, dysembryoplastic neuroepithelial tumor (DNET), ganglioglioma, pilocytic astrocytoma, papillary meningi- 

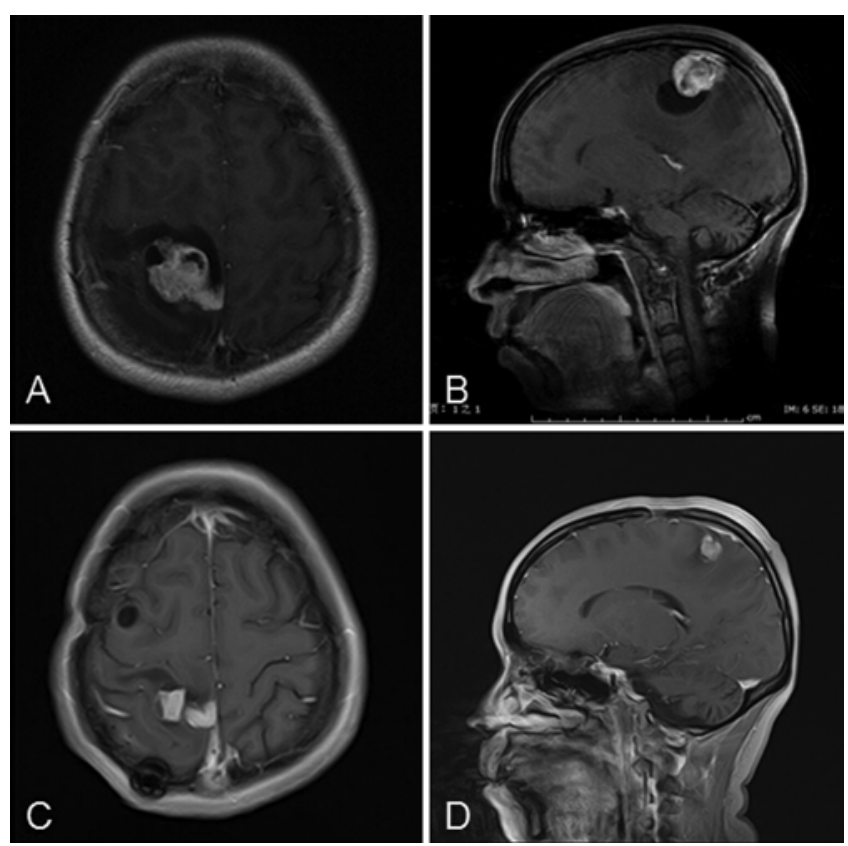

FIG. 3. Case 14. Preoperative enhanced T1-weighted MR images (A and $\mathbf{B}$ ) showing a cystic and solid lesion located in the right parietal lobe. Postoperative enhanced T1-weighted MR images (C and D) obtained 18 months after surgery, showing a solid tumor recurrence in situ.

oma, and astroblastoma. ${ }^{10,11,14,24,27-29}$ Although ependymal (true) rosettes or perivascular rosettes are pathognomonic for ependymal differentiation, ependymoma and its malignant counterpart demonstrated variable histopathological features such as tanycytic, epithelioid, and clear cell features. ${ }^{24,28}$ Electron microscopy may be supportive in the differential diagnosis by demonstrating zipper-like junctional complexes, microvilli, cilia with basal bodies, and intercellular microlumina containing variable numbers of microvilli and cilia. ${ }^{24,27}$
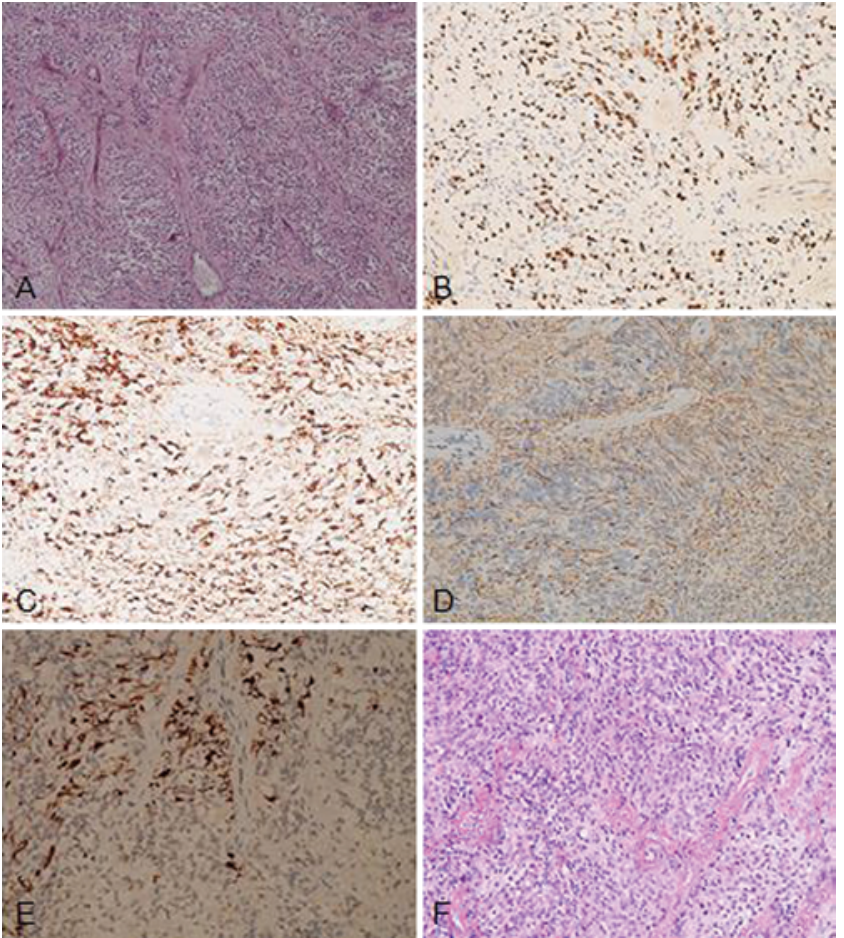

FIG. 4. The H \& E-stained sections demonstrated typical histological features of primary neurocytoma $(\mathbf{A})$ : small round tumor cells with neuronal differentiation and clear cytoplasm embedded in neuropil. Staining for NeuN was positive (B). Staining for synaptophysin was strongly immunopositive (C). Staining for GFAP was positive (D). Staining for S100 was partially positive (E). The $\mathrm{H} \& \mathrm{E}$-stained recurrent tumor tissue demonstrated increased cellularity with perivascular pseudorosettes and uniform ependymal cells (F). Typical characteristics of anaplastic ependymoma, such as nuclear atypia, mitotic activity, endothelial cell hyperplasia, and tumor necrosis were clearly observed. Original magnifications $\times 10(A$ and $F)$ and $\times 20(B-E)$. Figure is available in color online only.

TABLE 2. Summary of immunohistochemical outcomes in 14 cases of STE

\begin{tabular}{|c|c|c|c|c|c|c|c|c|c|c|c|}
\hline Case No. & Grade & GFAP & VIM & S100 & EMA & Nestin & MGMT & Olig-2 & Syn & Ki-67 & Others \\
\hline 1 & II & + & + & + & - & + & L+ & $L^{+}$ & - & $8 \%$ & CD34(+) \\
\hline 2 & III & + & + & + & $\mathrm{L}^{+}$ & ND & ND & ND & ND & $20 \%$ & \\
\hline 3 & III & + & + & + & + & ND & ND & ND & - & $30 \%$ & \\
\hline 4 & II & + & + & + & - & ND & ND & ND & - & $2 \%$ & CD56(+) \\
\hline 5 & III & + & + & + & L+ & + & ND & ND & - & $60 \%$ & \\
\hline 6 & II & + & + & + & $L^{+}$ & ND & ND & ND & - & $5 \%$ & \\
\hline 7 & III & - & + & + & + & ND & ND & ND & ND & $40 \%$ & p53(+) \\
\hline 8 & III & + & ND & ND & - & ND & ND & ND & ND & $5-8 \%$ & \\
\hline 9 & II & + & $L^{+}$ & + & + & ND & ND & ND & - & $5 \%$ & $\operatorname{CD} 57(+), \operatorname{MBP}(+)$ \\
\hline 10 & III & + & + & ND & + & + & ND & + & ND & $8 \%$ & \\
\hline 11 & II & + & + & + & - & $\mathrm{N}$ & + & + & + & $<1 \%$ & \\
\hline 12 & II & + & + & - & - & $\mathrm{L}^{+}$ & $\mathrm{L}^{+}$ & - & $\mathrm{L}^{+}$ & $5 \%$ & \\
\hline 13 & II & + & ND & ND & $\mathrm{L}^{+}$ & + & ND & ND & $\mathrm{L}^{+}$ & $5 \%$ & \\
\hline 14 & III & + & ND & + & - & ND & ND & ND & + & $8 \%$ & $\operatorname{NeuN}(+)$ \\
\hline
\end{tabular}

- = negative; + = positive; $L+=$ locally positive; $N D$ = not done; Syn = synaptophysin; $V I M=$ vimentin. 
With respect to ependymomas, the tumor location, patient age at diagnosis, histological grade, and extent of resection are major prognostic factors. ${ }^{15-17,19-21}$ However, other clinicopathological studies found no correlation between clinical outcome and tumor histological grade or other biological parameters, including p53 protein immunolabeling, proliferation markers, and tumor ploidy., 2,6,25,28 For supratentorial ependymomas, recent studies have suggested that radiotherapy should be conducted in patients with WHO Grade III tumors or in cases in which STR has been achieved. ${ }^{21,28-30}$ In the present study, radiotherapy was administered as an adjuvant treatment for STE after surgery. GTR of the lesion was performed in 12 cases. Radiotherapy was not performed for low-grade ependymoma (Grade II). Tumor-bed radiotherapy is strongly recommended for anaplastic ependymoma (Grade III) regardless of resection status and for low-grade ependymoma if removal is incomplete. No patients received chemotherapy. In the relatively short follow-up, tumors recurred in 3 cases (patients in 2 cases died) and all were diagnosed as WHO Grade III. The majority of recurrent ependymomas occurred at the initial tumor site. ${ }^{20}$ For relapsing cases, we also recommend surgery because the tumor is amenable to this procedure. ${ }^{21,28,30}$ Thus, histological grade and complete resection are believed to be potentially important prognostic factors for STE.

\section{Conclusions}

Supratentorial extraventricular ependymomas have atypical clinical presentations, various radiological features, and heterogeneous histological forms and often fail to yield a definitive diagnosis. Anaplastic ependymomas show malignant biological behavior, a higher rate of recurrence, and a relatively poor prognosis. From our limited experience with 14 STE cases, we believe that GTR with close surveillance is appropriate for low-grade STE. GTR accompanied by postoperative radiotherapy is recommended for anaplastic STE and low-grade STE if residual cancerous tissue remains after resection. Further information such as morphological features and molecular characterization, as well as treatment effectiveness and prognosis, are needed to facilitate optimal treatment guidelines.

\section{Acknowledgments}

This work was funded by the National Natural Science Foundation of Wuhan City (No. 2013060501010154).

\section{References}

1. Brat DJ, Scheithauer BW, Eberhart CG, Burger PC: Extraventricular neurocytomas: pathologic features and clinical outcome. Am J Surg Pathol 25:1252-1260, 2001

2. Bunyaratavej K, Shuangshoti S, Tanboon J, Chantra K, Khaoroptham S: Supratentorial lobar anaplastic ependymoma resembling cerebral metastasis: a case report. J Med Assoc Thai 87:829-833, 2004

3. Busse C, Nazeer T, Kanwar VS, Wolden S, LaQuaglia MP, Rosenblum M: Sacrococcygeal immature teratoma with malignant ependymoma component. Pediatr Blood Cancer 53:680-681, 2009

4. Chen L, Zou X, Wang Y, Mao Y, Zhou L: Central nervous system tumors: a single center pathology review of 34,140 cases over 60 years. BMC Clin Pathol 13:14, 2013
5. Curtis MA, Kam M, Nannmark U, Anderson MF, Axell MZ, Wikkelso C, et al: Human neuroblasts migrate to the olfactory bulb via a lateral ventricular extension. Science 315:1243-1249, 2007

6. Foreman NK, Love S, Thorne R: Intracranial ependymomas: analysis of prognostic factors in a population-based series. Pediatr Neurosurg 24:119-125, 1996

7. Furie DM, Provenzale JM: Supratentorial ependymomas and subependymomas: CT and MR appearance. J Comput Assist Tomogr 19:518-526, 1995

8. Guerrieri C, Jarlsfelt I: Ependymoma of the ovary. A case report with immunohistochemical, ultrastructural, and DNA cytometric findings, as well as histogenetic considerations. Am J Surg Pathol 17:623-632, 1993

9. Hegyi L, Peston D, Theodorou M, Moss J, Olver J, Roncaroli F: Primary glial tumor of the retina with features of myxopapillary ependymoma. Am J Surg Pathol 29:1404-1410, 2005

10. Lehman NL: Patterns of brain infiltration and secondary structure formation in supratentorial ependymal tumors. J Neuropathol Exp Neurol 67:900-910, 2008

11. Liu Z, Li J, Liu Z, Wang Q, Famer P, Mehta A, et al: Supratentorial cortical ependymoma: case series and review of the literature. Neuropathology 34:243-252, 2014

12. Louis DN, Ohgaki H, Wiestler OD, Cavenee WK, Burger PC, Jouvet A, et al: The 2007 WHO classification of tumours of the central nervous system. Acta Neuropathol 114:97-109, 2007

13. Louis DN, Perry A, Reifenberger G, von Deimling A, Figarella-Branger D, Cavenee WK, et al: The 2016 World Health Organization Classification of Tumors of the Central Nervous System: a summary. Acta Neuropathol 131:803820,2016

14. Lum DJ, Halliday W, Watson M, Smith A, Law A: Cortical ependymoma or monomorphous angiocentric glioma? Neuropathology 28:81-86, 2008

15. McGuire CS, Sainani KL, Fisher PG: Both location and age predict survival in ependymoma: a SEER study. Pediatr Blood Cancer 52:65-69, 2009

16. McGuire CS, Sainani KL, Fisher PG: Incidence patterns for ependymoma: a surveillance, epidemiology, and end results study. J Neurosurg 110:725-729, 2009

17. Metellus P, Figarella-Branger D, Guyotat J, Barrie M, Giorgi R, Jouvet A, et al: Supratentorial ependymomas: prognostic factors and outcome analysis in a retrospective series of 46 adult patients. Cancer 113:175-185, 2008

18. Mikami M, Komuro Y, Sakaiya N, Tei C, Kurahashi T, Komiyama S, et al: Primary ependymoma of the ovary, in which long-term oral etoposide (VP-16) was effective in prolonging disease-free survival. Gynecol Oncol 83:149-152, 2001

19. Niazi TN, Jensen EM, Jensen RL: WHO Grade II and III supratentorial hemispheric ependymomas in adults: case series and review of treatment options. J Neurooncol 91:323-328, 2009

20. Oya N, Shibamoto Y, Nagata Y, Negoro Y, Hiraoka M: Postoperative radiotherapy for intracranial ependymoma: analysis of prognostic factors and patterns of failure. J Neurooncol 56:87-94, 2002

21. Palma L, Celli P, Mariottini A, Zalaffi A, Schettini G: The importance of surgery in supratentorial ependymomas. Long-term survival in a series of 23 cases. Childs Nerv Syst 16:170-175, 2000

22. Parish JM, Bonnin JM, Goodman JM, Cohen-Gadol AA: Intrasellar ependymoma: clinical, imaging, pathological, and surgical findings. J Clin Neurosci 22:638-641, 2015

23. Roncaroli F, Consales A, Fioravanti A, Cenacchi G: Supratentorial cortical ependymoma: report of three cases. Neurosurgery 57:E192, 2005 
24. Rosenblum MK: Ependymal tumors: a review of their diagnostic surgical pathology. Pediatr Neurosurg 28:160-165, 1998

25. Schiffer D, Chiò A, Giordana MT, Migheli A, Palma L, Pollo B, et al: Histologic prognostic factors in ependymoma. Childs Nerv Syst 7:177-182, 1991

26. Schwartz TH, Kim S, Glick RS, Bagiella E, Balmaceda C, Fetell MR, et al: Supratentorial ependymomas in adult patients. Neurosurgery 44:721-731, 1999

27. Shuangshoti S, Mitphraphan W, Kanvisetsri S, Griffiths L, Navalitloha Y, Pornthanakasem W, et al: Astroblastoma: report of a case with microsatellite analysis. Neuropathology 20:228-232, 2000

28. Shuangshoti S, Rushing EJ, Mena H, Olsen C, Sandberg GD: Supratentorial extraventricular ependymal neoplasms: a clinicopathologic study of 32 patients. Cancer 103:2598-2605, 2005

29. Van Gompel JJ, Koeller KK, Meyer FB, Marsh WR, Burger PC, Roncaroli F, et al: Cortical ependymoma: an unusual epileptogenic lesion. J Neurosurg 114:1187-1194, 2011

30. Vinchon M, Soto-Ares G, Riffaud L, Ruchoux MM, Dhellemmes P: Supratentorial ependymoma in children. Pediatr Neurosurg 34:77-87, 2001

\section{Disclosures}

The authors report no conflict of interest concerning the materials or methods used in this study or the findings specified in this paper.

\section{Author Contributions}

Conception and design: Shu, Sun. Acquisition of data: Sun, Gao, Zhang, Jiao. Analysis and interpretation of data: Sun. Drafting the article: Sun. Critically revising the article: Sun, Wang, Zhu, Beejadhursing. Reviewed submitted version of manuscript: Shu, Sun. Approved the final version of the manuscript on behalf of all authors: Shu. Statistical analysis: Sun. Administrative/technical/ material support: Jiang, Ke. Study supervision: Shu.

\section{Correspondence}

Kai Shu, Department of Neurosurgery, Tongji Hospital, Tongji Medical College of Huazhong University of Science \& Technology, 1095 Jiefang Ave., Wuhan, Hubei 430030, PR China. email: kshu@tjh.tjmu.edu.cn. 